\title{
IF THERE IS A HOLE IT IS NOT GOD-SHAPED
}

\section{Guy Kahane, Oxford University}

In a letter that Bertrand Russell wrote to his then lover Colette O'Neil, he confesses that

The centre of me is always and eternally a terrible pain - a curious wild pain - a searching for something beyond what the world contains, something transfigured and infinite - the beatific vision - God...

In an earlier letter to Lady Ottolline Morrell, another lover who was a religious believer, Russell wrote,

Turbulent, restless, inwardly raging — I shall always be - hungry for your God and blaspheming him. I could pour forth a flood of worship - the longing for religion is at times almost unbearably strong. ${ }^{2}$

Russell was of course an avowed atheist, a lifelong critic of Christianity. ${ }^{3}$ But the state of mind he reports is not inconsistent or even uncommon. Russell rejected theism, yet found the godless universe that we inhabit grim and deeply unsatisfying. Something is missing - the thing that, for religious believer, is supplied by God. There is a religious yearning in him that cannot be fulfilled in a universe governed merely by blind, indifferent natural forces. So while Russell didn't believe in God, he ardently wished that God had existed. We can call this combination of attitudes protheist atheism. ${ }^{4}$

The cliché says that the theist's God-shaped hole is the atheist's hole-shaped God. If atheism is true, then both claims could be correct: we may feel a deep lack, something missing in our worldly existence. And wishing to believe that there is something out there that would fulfil this lack, some of us project a divine being, 'shaped' exactly to address that need, onto the cosmos. ${ }^{5}$

We could understand the metaphor of the 'God-shaped hole' in phenomenological terms, as merely a claim about the psychology of some people. I

${ }^{1} 23$ October 1916. Cited in Monk (1996, 316).

227 December 1911. See Griffin (2013, 394). Nagel (2009) includes Russell in the list of analytic philosophers who lack what Nagel calls 'religious temperament'. As this letter shows, that isn't quite right.

${ }^{3}$ Russell sometimes described himself as an agnostic but by this he just meant that he didn't have proof that God doesn't exist. He claims to be similarly agnostic about the Homeric gods, and to regard neither to be 'sufficiently probable to be worth serious consideration'. See Russell (1950).

${ }^{4}$ See Kahane (2011); Rescher (1990) calls a similar view 'axiological theism'. Notice that I understand pro-theism and anti-theism to be claims about attitudes to God's existence, not about its value. While what we are justified in preferring, regretting or fearing often reflects differences in the balance of value, the former needn't be a simple function of the latter. Some responses to my article have understood these terms in straight axiological terms, ignoring this further step between value and attitude.

${ }^{5}$ Of course, for the theist the explanation goes in the other direction. As Augustine wrote, "you made us for yourself, O Lord, and our heart is restless until it rests in you." (Augustine 2008, 3) 
am not interested here in this psychological question. I'm interested in this metaphor as a substantive claim: the view that something essential is missing in the naturalist universe we inhabit, a universe that Samuel Beckett described as a 'world of desolation', 6 and which is governed, as Richard Dawkins put it, by 'nothing but pitiless indifference'?

Before ending with this phrase, Dawkins (2008) describes our universe as one with 'no design, no purpose, no good, no evil....' I assume that Dawkins means that the naturalist universe itself is neither morally good or evil (or, indeed, morally anything), nor created by a being with such properties. But that isn't the same as to hold that the naturalist universe doesn't contain good or bad things, or that it cannot as a whole be said to be overall good or bad. Now some do hold that God is the source of all value, which would mean that in the absence of God it would make no sense to ascribe value to anything. But if there is no value then God's absence cannot be a bad thing either, or make our lives worse. If nothing matters then that fact also doesn't matter. ${ }^{8}$ Russell has no reason to feel such agony — not that his agony would matter anyway. So we can set aside nihilism here. ${ }^{9}$

Russell presumably thinks that our naturalist universe is in some way worse than the theist alternative that Lady Morrell believes in. But the mere fact that something is overall worse than some conceivable alternative is hardly a reason for existential anguish. Even the most extraordinary things could be bettered. Hamlet or the Sistine Chapel aren't unimprovable. But this doesn't make them any less wonderful. Shouldn't we at least prefer that things had been better, if they could have? Even that isn't obvious. Perhaps we should be satisfied with what's very good, or even just good enough. And anyway, such a pale preference for a better alternative isn't the same as thinking that this alternative really matters.

Russell might hold that the naturalist universe is overall bad-in the sense that the overall balance of value in it is negative. That would be a form of pessimism in the Schopenhauerian mould. But Russell's anguish is obviously not a response to all the agony around him. And it's anyway hard to place an overall value on our universe. Things here on Earth aren't going so well right now, to be sure, but can we really say with confidence that they have overall positive or negative value? And the future of humanity might extend billions of years into future, which could contain wondrous utopias, or endless misery. And that's just referring to us humans. For all we know, there might be countless intelligent forms of life scattered around the universe, and our miserable performance might be an aberration. Or we might be the only ones in this vast cosmos. ${ }^{10}$

${ }^{6}$ Beckett attributes the desolation to the discovery that we are 'a speck of dust in a vast universe.' (see Buttner, 2002). A. S. Byatt (1967) describes “a sense of lack which becomes intolerable. If there is not more love in the world than human beings supply, life is unlivable; if life has no purpose or meaning beyond work, charity and the acquisition of knowledge, one is better dead; if there is no authority to dictate, judge, punish or forgive our acts, our lone moral responsibility becomes so haphazard and at the same time so strenuous that we cannot act." See also Mavrodes (1986).

${ }^{7}$ A. E. Housman had earlier complained about the 'heartless witless nature' $(1922 / 2010,132)$ and Nietzsche spoke of a "de-deified world that has become stupid, blind, crazed and questionable". (Nietzsche, 2001, 220-221).

${ }^{8}$ See Nagel (1971). I elaborate this point in Kahane (2016).

${ }^{9}$ This isn't to deny that some atheist do worry about these supposed nihilist implications of God's absence. Camus may be one example and, following Dostoevsky, Sartre (2007) claims that we humans are 'forlorn' because in the absence of God everything is permissible. But I think this is confused. See Kahane (2016).

${ }^{10}$ See Kahane (2014). 
We don't know how good or bad our universe is overall. Can we at least know that, in the absence of God, our own lives are bad? That would easily justify Russell's despair, and his longing for God. But although Russell wasn't a happy soul, his extraordinary life seems far from a life that is overall bad - the kind of life, as some would say, that isn't worth living. Nor does Russell cite failure or misery in explaining why he longs for God-he is feeling that terrible pain because God doesn't exist.

It would be better, I think, to understand Russell's anguish, or the metaphor of a 'God-shaped hole', not in terms of positive badness, or the complete absence of value, but in terms of the absence of sufficient good. It's not that things are bad, not even that they lack overall positive value. But our lives aren't good enough, they lack certain essential goods that are simply missing from the kind of universe in which find ourselves. ${ }^{11}$

This claim can be stated impersonally, at the level of the universe. You might say: the universe itself has a 'God-shaped hole', it's not just that it could have been better, but it is missing something essential. After all, the fundamental axiological fact about our universe isn't the misery down here in Earth but (setting aside aesthetic value) the utter absence of value in the vastness that surrounds us - outer space is an amazing waste of space. ${ }^{12}$

As experienced by Russell and others, however, the lack that is supposed to follow from God's absence seems a self-focused matter: there are certain things that our lives need to be genuinely satisfying and that we simply cannot have if there is nothing beyond or outside nature. ${ }^{13}$ Such dissatisfaction with the world as we find it, and a sense that the lives we can lead in it are fundamentally lacking, is a recurring sentiment in the modern era. It is also, I think, an underappreciated source of social unrest and upheaval. ${ }^{14}$

I have to confess that, at least in some moments, I feel something like this lack, even though in nothing approaching the dramatic form that Russell reports. Now this sense of lack may well be illusory, but my aim here is neither to defend nor to dismiss it. ${ }^{15}$ What I shall argue is that if there is such a 'hole', it is not God shaped. If belief in God is a projection of that existential need, it is based on a double mistakenot just the mistake of the projection, but the further mistake of projecting the wrong thing.

${ }^{11}$ We can understand what is missing in terms of quantity: our brief, discontented mortal life is obviously less than an immortal blissful one. But we might also be missing certain kinds of goods that are lexically superior to what's around us_-perhaps sacred beings and (true) mystical visions.

12 Whatever one makes of the fine-tuning argument, our universe is at best fine-tuned to allow for a tiny bit of value, perhaps only in some miniscule remote corner, as opposed to numerous naturalist alternatives that would have contained none. It is most certainly not especially fine-tuned to promote value, let alone to maximize it.

${ }^{13}$ Nagel (2009) describes a similar view: "Outrageous as it sounds, the religious temperament regards a merely human life as insufficient, as a partial blindness to or rejection of the terms of our existence. It asks for something more encompassing, without knowing what that might be." Notice that we can make parallel claims about meaning. While it's similarly implausible that in the absence of God there can be no meaning in human life (cf. Wolf, 2010), and Russell's life certainly seems meaningful, one may nevertheless hold that naturalist lives don't have enough meaning.

${ }^{14}$ Since modernity involved both a shift in metaphysical view and a radical transformation of our form of life, such dissatisfaction may be due to the latter at least as much as to the former. Perhaps the so-called 'hole' is tribe-shaped...

${ }^{15}$ For further discussion of the idea that something fundamental might be missing in a naturalist universe, see Taylor (2010); Habermas (2010). 
I should note, however, that my core argument doesn't assume that our lives are lacking something essential. Even if there isn't such a 'hole', it's obvious that the actual world contains a great deal of misery, and could have been vastly better. Even if we ask how things might have been different, and better, more out of curiosity than out of Russell's despair, our reflections shouldn't lead us to wish that God had existed.

While my argument will be developed from an atheist perspective, it also has implications for theists. If I am right - though I don't expect theists to accept the value claims I will rely on - then theists have reasons to want God not to exist. To stretch the clichéd metaphor to the limit: theists should wish that the universe had a large hole where God now majestically looms. Even God cannot bring us true satisfaction.

\section{NATURALISM, NOT ATHEISM}

Let me start with some important preliminaries. Russell was an atheist, but this actually tells us little about his metaphysical views. The point is familiar: atheism is merely a negative claim, a denial of God's existence. The range of views that count as atheist in this sense is large. These include Polytheism, Manichaeism, solipsism, the idealism of Hegel or Fichte or of F. H. Bradley or McTaggart, Schopenhauer's malignant cosmic will, Aristotelian teleology (perhaps sans Unmoved Mover), NeoPlatonism and other forms of axiarchism, Daoism, the metaphysics of Karma and rebirth, and very many others. ${ }^{16}$ This list of views obviously doesn't mark an interesting metaphysical grouping - except perhaps for a theist.

Of course when someone is described as an atheist we would today also assume that they are naturalists of some sort - that they reject not only the existence of God and His angels, but the supernatural more generally, and that they take the world to be, at least in its ground-level ontology, to be roughly as described by fundamental physics. ${ }^{17}$ Russell was a naturalist, broadly speaking, for large parts of his life (he had started out flirting with idealism), and I think that the anguish he describes makes sense only against this background. ${ }^{18}$

Now it's obvious that the naturalist universe we inhabit is far from being the best of all possible worlds. There are so many ways in which things could have been better. That's hardly surprising: it is precisely a key feature of such a universe that it's not the product of a supreme designer, and not governed by any purpose or value.

However, to find the universe around you unsatisfying isn't yet to be dissatisfied with naturalism itself. After all, very many ways in which things might have been better would still count as naturalist, at least if we understand this term loosely enough. ${ }^{19}$ A steady state universe with no Big Bang would still be naturalist. The Copenhagen interpretation of quantum mechanics and Everett's multiverse

${ }^{16}$ Some of these views can admittedly be interpreted as highly non-standard forms of theism: Neo-Platonists believe in 'the One', Idealists in the Absolute, and Hegel had his peculiar conception of God. As will be explained below, I will understand theism here along more orthodox lines.

17 The identification of atheism with 'materialism' goes a long way back. Cudworth already wrote that "all Atheists are mere Corporealists, that is, acknowledge no other Substance besides Body or Matter ..." (Cudworth 1678: I, iv, 187).

${ }^{18}$ See especially Russell (1903).

${ }^{19}$ I will not offer any very precise definition of 'naturalism' but I will understand the view to involve a metaphysical claim about the kinds of things that exist — and the kind that don't. But for my purposes it doesn't matter if these metaphysical claims depend on some prior methodological view. I'll also just assume that attempts to interpret theism in naturalist terms are really just atheism in disguise. 
describe profoundly different cosmic orders, but both are (or can be) naturalist. Moving on to philosophy: behaviourism, the identity theory and functionalism (and even certain forms of panpsychism ${ }^{20}$ and dualism ${ }^{21}$ ) in philosophy of mind, or ethical naturalism, constructivism and noncognitivism in metaethics ${ }^{22}$ - these and many other philosophical positions all attempt to describe the actual world, but even if they fail, they still describe possible naturalist worlds - which we may evaluate as more or less attractive than the actual one. ${ }^{23}$

It should be obvious, then, that to simply ask whether we should prefer theism to atheism, or whether one describes a superior universe to the other, is almost meaningless. Atheism does not refer to a positive metaphysical view, and the different views falling under it have little in common, and are likely to wildly diverge in value.

Moving from atheism to naturalism narrows down the options considerably, but, as we just saw, naturalism can take multiple forms and conceivable naturalist universes will still differ in content and value. We can narrow down our focus to the actual naturalist universe we happen to inhabit - but now we are certainly no longer comparing theism and 'atheism'. We are comparing the highly specific version of naturalism we find in the actual world and an alternative in which God does exist.

Even this narrow comparison remains indeterminate, now in the other direction. Theism can also take very many forms. The deity described in early monotheist texts is distinctly unappealing, and is rather different from the God of the Philosophers. In what follows, I will assume a fairly standard if not uncontroversial understanding of theism on which it refers to the claim that there exists an omnipotent, omniscient and omnibenevolent supernatural person who is the creator of the universe (many theists would add that God is a necessary being - a complication I will attend to only at the very end). I will also largely abstract away from the further elaborations of any concrete theist religion.

Even so, the theist alternative can still be understood in at least two ways. On one, Russell might be comparing the actual naturalist world with the way the world would have been had a theist like Lady Morrell been right. So we envisage a world that overlaps with ours in many respects (Russell's biography and prior human history stay more or less the same) but in which God does exist, and e.g. when Russell dies he might go to heaven and ask God why He didn't provide more evidence. ${ }^{24}$

Such a comparison may be especially appropriate for an agnostic or wavering atheist since for such a person both alternatives describe the way things may actually be. But it's less clear why confident atheists, at least those who take the problem of evil seriously, should focus on this way of understanding the theist alternative. After all, here they would be conceiving of a possibility in which their various reasons for thinking that God exists - including all the suffering and misery around - turn out to be mistaken. But why focus on that as opposed to the very different, and far rosier world, in which God exists and, indeed, prevents all that suffering from occurring in

${ }^{20}$ See Strawson (2008).

${ }^{21}$ See Chalmers (2007).

22 To the extent that certain forms of non-naturalism about normativity and mathematics don't have ontological commitments, as some claim, then they might also be compatible with metaphysical naturalism (Cf. Parfit, 2011; Scanlon, 2014).

${ }^{23}$ Our present inability to resolve most of these debates adds a further limit to our ability to confidently speak about the overall value of the actual universe.

${ }^{24}$ For further discussion of how to state such a comparison more precisely, see Kraay and Dragos (2013). 
the first place? $?^{25}$

\section{THE AXIOLOGY OF NATURALISM}

Russell seems unhappy with the actual naturalist world, which he compares unfavorably with a theist alternative. To make such large-scale evaluations of the naturalist universe is to engage in what we can call the axiology of naturalismthough our verdict needn't be so negative, or so desperate. This is a strangely neglected project, especially given that so much of analytic philosophy since the mid $20^{\text {th }}$ century (as well as earlier on) has been concerned with offering naturalist accounts of our core commonsense notions - morality, free will, consciousness, intentionality, and so forth. ${ }^{26}$ Presumably, it matters whether such accounts can be given and what shape they will take. It presumably matters, for example, whether we do have free will and if so, whether we have it in a variety worth wanting ${ }^{27}$ - which is just to say, in a variety that it would be good or better to have, compared to alternatives. ${ }^{28}$

Sketching what an axiology of naturalism will involve is beyond the scope of this chapter. It should be obvious by now that it can involve far more than comparisons between the naturalist world and theism. There are many relevant comparisons that we can make within a broadly naturalist framework, and even when we step beyond naturalism, there are numerous atheist metaphysical systems that may call on our attention. In fact it's far from obvious that theism has a privileged role-or indeed any interesting role at all - in an axiology of naturalism. After all, for a confident atheist, its only salience is historical and sociological. Why should Russell privilege it over, say, the idealist metaphysics of his youth? To the extent that you take theism to be a serious possibility, this higher probability may endow it with greater significance - since it might after all be true that things are better (or worse) in this way. But I take it that for the confident atheist, theism isn't significantly more probable than McTaggart's idealism or, for that matter, the Berkeleyian universe described in Borges's fiction Tlon, Ukbar, Orbius Tertius (we can set aside spaghetti monsters...).

This dismissal of theism may seem confused. God, it will be objected, is supposed to be the most perfect being we can conceive. Even if we deny that God exists, what we are denying is the existence of this perfect being. And this analytic point is sufficient to establish the axiological primacy of God within any space of metaphysical possibilities, however wide or wild. Whatever our location in metaphysical space, we have reason to turn our rapt attention to God, whether as actual or, with regret, as merely possible being.

I will call this view Superior World Pro-Theism. In its strong form, the claim

${ }^{25}$ See Kahane $(2011,680$, fn. 11). When we compare worlds in this way, we might be concerned with the impersonal comparison of their overall value. Or we can make these comparisons from the personal perspective, asking which of the relevant possibilities would be (or would have been) better or best for us. Needless to say, the latter comparisons only make sense if we exist in both possibilities. Spelling out the conditions under which we can make this assumption with any degree of plausibility is beyond the scope of this chapter. But it should be obvious that we can make personal comparisons only of a small subset of the total space of atheist and theist worlds.

${ }^{26}$ See e.g. Jackson (1998).

${ }^{27}$ Dennett (1984). Within specific debates, there's certainly work that makes an important contribution to the axiology of naturalism. But this question is rarely treated generally or systematically.

${ }^{28}$ Kahane (2013). 
would be that any theist universe is superior to all atheist ones. For my purposes here, we can focus on the more qualified claim that at least some theist worlds are superior to all atheist ones.

There is prima facie plausibility to this view. But I'll argue that it is mistaken. God may be the perfect being, but His existence doesn't make for the perfect universe. To put this differently: we shouldn't assume that theism describes the best of all possible metaphysics.

\section{AMBIVALENT PRO-THEISM}

Needless to say, many atheists don't share Russell's tormented longing for God. But my impression is that (to the extent that they have considered the question) atheists tend to lean pro-theist. For example, Colin McGinn recounts that giving up religious belief was, for him, not a relief but a disappointment. He goes on to explain that

"I would have liked religion to be true. I'd like it to be true, because I'd like to be... I'd like there to be immortality, I'd like there to be rewards for those who have been virtuous and punishments for those who've not been virtuous... You know, there's not... there's no justice in this world and it would be good if there was some cosmic force that distributed justice in the proper way that it should be..." (Miller, 2004)

This appears to express McGinn's overall attitude: it is regrettable that there is no God. Yet he also immediately adds remarks that point in an anti-theist direction:

“... there was some exhilaration too. I mean... Russell has a description that I think is kind of appropriate of a feeling of a Godless universe as a kind of exhilarating universe. There's something hygienic about it. There's something bracing about it. Whereas the idea that there's this sort of... suffocating presence gazing at your every movement and thought... you know... and gauging everything you do... it's a bit oppressive to think that way." (Miller, 2004)

We can call McGinn an ambivalent pro-theist. He wants God to exist but he also recognizes that there is a serious downside to having God around-and that a godless world has its distinctive attractions. ${ }^{29}$

Paraphrased in explicit axiological terms, McGinn seems to hold that God's existence would be bad in certain important respects yet, nevertheless, the world is overall made considerably worse by His absence, which is therefore regrettable-i.e. the cost of suffocating surveillance and constant assessment is well worth paying if we get immortality and cosmic justice in return.

This gives us the following argument for pro-theism:

Theism Is Better In Respect (TBR). If God had existed, this would have been better in important respects (because we could enjoy immortality and because cosmic justice would prevail).

Theism Is Worse In Respect (TWR). If God had existed, this would have been worse in other important respects (because of the inescapable intrusive judging surveillance).

${ }^{29}$ It's not clear whether McGinn thinks that a godless (naturalist) universe is 'hygenic' and 'bracing' simply because it frees us from the bad aspects of theism or because of its further positive features-features not to be found, for example, in many supernatural atheist metaphysical systems. 
Theism Is Better Overall. The ways in which God's existence would make things better outweigh the ways in which would make it worse (because, for McGinn, immortality + cosmic justice $>$ no divine surveillance).

Therefore

Pro-Theism. We should prefer a world in which God exists to the actual natural universe.

It would be hard to deny that the existence of an all powerful and supremely benevolent being would make the world significantly better in some respects. ${ }^{30}$ The world would be a better place if cosmic justice was upheld, and (blissful) immortality does sound nice. Still, not everyone accepts McGinn's conclusion. Thomas Nagel famously remarked,

"I hope there is no God! I don't want there to be a God; I don't want the universe to be like that." (Nagel, 1997)

Nagel is expressing here a strong antitheist sentiment. He is afraid of the possibility that God does exist. Nagel doesn't elaborate on this remark or try to defend it. His attitude is certainly puzzling: rejecting cosmic justice seems callous, rejecting immortality foolish. In earlier work, however, I have argued that this challenge can be met, and that an antitheist attitude is defensible (see Kahane, 2011). My argument made much more of the downside of God's existence than McGinn does in the passage above. Although it would be hard to deny that a world in which God exists is overall impersonally better than a naturalist alternative, I argued that the impositions that God's existence would make on our lives can justify a rejection of such a world, at least from our personal perspective. ${ }^{31}$

As I interpret Russell, McGinn and Nagel, they are all implicitly making what we can call actual world comparisons: they are comparing the actual world, understood in naturalist terms, with a theist alternative — which, as we saw, can be construed as more or as less distant. The opposing verdicts that they give on the basis of such comparisons we can call actual world pro- and anti-theism.

The anti-theist argument I shall develop in this chapter will not defend antitheism in this sense. In fact, although my argument here partly overlaps my earlier argument, it's an independent argument that is compatible with siding with the answer that Russell and McGinn (and presumably most or all theists) give to the above question.

The basic idea is simple. Notice that while the benefits mentioned in TBR are expected upshots of God's existence, they do not inherently require God's existence. The Karmic cycle is one mechanism of cosmic justice that could easily also operate in a godless world. Even heaven and hell (if one wants to tie immortality and cosmic justice in this way) could run just fine without a divine overlord. At the same time,

\footnotetext{
${ }^{30}$ See Kahane (2011). Though antitheists may well reject the specific advantages that McGinn finds in a theist universe. Many find the idea of divine punishment unpleasant and one may find, with Bernard Williams (1973) the prospect of immortal life unappetizing.

${ }^{31}$ For responses, see Mawson (2012); Luck \& Ellerby (2012); Kraay \& Dragos (2013); Kraay (2013); Penner (2015); Dumsday (2016); Penner \& Lougheed (forthcoming); for criticism of Nagel, see McLean (2015).
} 
God's existence would entail a continuous intrusion into our privacy, on the standard understanding of the concept of God. ${ }^{32}$

In other words, you can't have God without the negative stuff but you can have the positive stuff without God-and thus without the negative stuff. So the best possible worlds are ones in which we still enjoy the benefits of a Godly world but where God doesn't exist. That is to say, the most attractive possible worlds are atheist. Call this the Argument for Superior Atheist Worlds.

Of course, the actual naturalist world isn't one of these superior worlds (or even close to being one). And it's likely that these worlds are supernaturalist atheist worlds. Though, depending on the relevant set of goods, and on how loosely we understand 'naturalism', it can hardly be ruled out in advance that we could enjoy many of these goods in a conceivable naturalist universe.

\section{THE ARGUMENT FOR SUPERIOR ATHEIST WORLDS}

Let me set out this argument explicitly:

(A) If God had existed, this would necessarily make things better in important respects (TBR).

(B) If God had existed, this would necessarily make things worse in other important respects (TWR).

(C) All (or at least most) of the benefits under (A) could be had without God.

Therefore

(D) There are possible atheist worlds that offer all (or most) of the benefits of God's existence but without the costs.

Therefore

(E) Some atheist worlds are overall the best, or among the best, and are superior to all theist alternatives.

Therefore

(F) The worlds we should most prefer are atheist worlds.

Most of the rest of this chapter will be devoted to defending the premises of this argument. I take it that (A) is not under dispute here-at least not on the assumption that God is supremely benevolent. Premise (C) also seems to me fairly straightforward. Premise (B) is probably the most controversial, and will require the most elaboration. As we shall see, it may require some fine-tuning.

Both (A) and (B) are claims about the value of aspects of the relevant worlds. Premise (E), by contrast, is a claim about the overall value of worlds. I think that the conclusion in (E) can be made from both impersonal and personal perspectives, where the latter is understood not as referring just to mine or your individual standpoint but to that of all existing persons (that is, all persons who aren't God...). But in order to support (F) it will be sufficient if some atheist worlds are better for us, and if theist worlds are not significantly impersonally better. Finally, in order to address

${ }^{32}$ By contrast, while some form of cosmic justice is probably entailed by God's existence, this is less obvious for immortality — so far as I can see, theists believe in immortality on the basis of revelation; it's not a simple entailment of God's omnibenevolence; perhaps, for example, we humans possess greater value to God as more ephemeral beings. 
complications due to the possibility of infinite value, (E) states that some atheist worlds are superior to all theist alternatives, even if they cannot be described as overall better.

The conclusion of this argument amounts to what I call superior world antitheism. This view is based on comparisons that range over the whole space of possible metaphysical views. It claims that the best atheist worlds are superior to the best theist worlds - that these atheist worlds are the ones we should prefer the most.

This claim is obviously independent of our answer to the narrower comparison between the naturalist world that we seem to actually inhabit and a theist alternative. It is compatible with both pro-theism and anti-theism in the actual world sense. As we shall see later, one upshot of my argument here is that it puts that narrower comparison in a broader axiological context - and reveals it to be less important than it may seem at first.

\section{GODLY GOODS WITHOUT GOD}

Let us start with the claim all (or at least most) of the benefits of God's existence can be had without God. McGinn mentions cosmic justice and immortality (presumably of the heavenly kind), and these are high on most pro-theist lists. Some would also want to perhaps add a more enchanted, meaning-laden world, (true) mystic union with the universe as a whole, a harmonious, supernatural order, and so forth. And those who think that if God doesn't exist and our universe is a naturalist one then nothing will have value, or that there could be no objective morality or meaning to our lives, or that we couldn't have free will, will presumably add these to their listthough it's far from obvious that naturalism has these implications.

The point though is that it's hard to see why God is needed for any of these goods. Again, cosmic justice and immortality in no way require a god-in fact, it is easy enough to conceive of thoroughly naturalist worlds that would offer these benefits. ${ }^{33}$ And even if you thought that value or objective morality or libertarian freedom are incompatible with naturalism, this doesn't yet mean that they require God-there are numerous possible worlds that are godless but not naturalist. ${ }^{34}$

It might be objected, however, that the above list of divine benefits is too short. This objection can be made both at the level of impersonal value and that of personal value. At the level of impersonal value, there is God's own value: if God is a perfect being then surely it follows that He must be of immense, even infinite value ${ }^{35}$ Notice though that even if God is the most perfect being, and perfectly morally good, this doesn't immediately entail a claim about the value that God adds to a world. But I agree that it would be hard to deny that God would possess immense value, a value

${ }^{33}$ Klaas Kraay has suggested to me that the character of these goods may be different, and more desirable, in a Godly world. Cosmic justice, for example, has a different character when meted out by God than by an impersonal force that cannot blame or forgive. But while these goods may be different in character in a Godly world, this difference doesn't seem to me importantly better. And if it is, we may be able to get it without God-for example, cosmic justice can have its noumenal source the collective verdict of all good persons.

${ }^{34}$ While I can't see any argument that would exclusively tie free will or meaning to a divine source as opposed to a super-natural one, views such as the Divine Command Theory do attempt to do so for morality or even value. There is obviously no need to rehearse here the arguments against such a view, arguments that many theists accept. In addition, it needs to be shown that some non-divine supernatural source can't do the relevant work.

${ }^{35}$ See Kraay and Dragos (2013, 168); MacLean (2015) and especially Penner and Lougheed (forthcoming). 
obviously be missing from any atheist world. I'll consider below how this bears on verdicts about the comparative value of theist and atheist worlds.

Now few of those who yearn for God do so because they worry that His immense value is missing from our world. But it might be objected that there are fundamental personal goods that do inherently involve God: e.g. having a personal relationship with a supreme being who is also one's creator, and the creator of the universe, and worshipping and being faithful to such a being, etc. ${ }^{36}$

It's not surprising that theists consider these to be great goods, but I doubt that they will be attractive to many atheists. I don't myself find the idea of such a relationship with a supreme being so appealing, and I see little plausibility in the idea that "final and perfect happiness can consist in nothing else than the vision of the Divine Essence" (Aquinas 2006, 1103; unlike Russell, I wasn't brought up in a Christian school).

By contrast, pro-theists who aren't also devout believers tend to cite the afterlife and cosmic justice, as McGinn does. Freud, for example, wrote that "it would be very nice if there were a God who created the world and was a benevolent providence, and if there were a moral order in the universe and an afterlife" (1990, 215) and both Mill (1874) and Sidgwick (1907) hoped that there is such an afterlife. The physicist Steven Weinberg (2008) similarly writes that

"The more we reflect on the pleasures of life, the more we miss the greatest consolation that used to be provided by religious belief: the promise that our lives will continue after death, and that in the afterlife we will meet the people we have loved."

Theists who defend pro-theism also often appeal to such goods ${ }^{37}$ - which are also included, for example, in the 'good news' that Christianity is supposed to deliver. But these goods are surely God-independent.

So if the theist presses these supposed God-dependent goods, the atheist can just shrug in reply. In any event, it seems to me that even these goods don't ineliminably involve God-as opposed to someone who is immensely powerful, knowledgeable and nice.

\section{WORSE IN RESPECT: THE EXAMPLE OF PRIVACY}

If we could have the benefits of God's existence without God then this should be enough to make it permissible to prefer a godless world that contains these benefits over a Godly one; after all the two worlds would be of broadly equal value. It's the second premise of the argument that is supposed to support the stronger claim that such godless worlds are superior to Godly ones. To remind you, that premise was

Theism Is Worse In Respect (TWR). If God had existed, this would have been worse in important respects.

The next few sections will be devoted to defending this premise. Since TWR was also a key premise in my earlier argument for 'actual world' anti-theism, what I say here should also bolster that other argument.

If God is a supremely good being, indeed the perfect being, how could His existence make things importantly worse in any way?

${ }^{36}$ See Klaas and Dragos $(2013,168)$.

${ }^{37}$ See e.g. Kraay and Dragos (2013); Davis (2014); MacLean (2015). Adams's (1979) moral argument for theism also appeals to the idea of a cosmic moral order. 
To see how, it might be useful to start with an example already mentioned, that of loss of privacy. I quoted above McGinn's remarks about a 'suffocating presence gazing at your every movement and thought... and gauging everything you do.' (Miller, 2004) And Sartre tells the story of how, as a child, he last felt the presence of God as a judging gaze observing him illicitly playing with matches in the bathroom, leading Sartre to respond with outrage at God's 'indiscretion' (Sartre 1964, 102). This is a common anti-theist concern, but I must emphasize that I start with it not because it's the strongest anti-theist concern — whether in force or plausibilitybut because it's the clearest.

Some theists acknowledge this concern. Plantinga writes that "many people thoroughly dislike the idea of an omnipotent, omniscient being monitoring their every activity, privy to their every though, and passing judgment on all they do or think." (Plantinga 2000, 195). Elsewhere he remarks that 'some will find in theism a sort of intolerable invasion of privacy: God knows my every thought, and indeed knows what I will think before I think it,' (Plantinga 2012) and he points to an ancient expression of this discomfort in the Old Testament:

"Before a word is on my tongue, you know it completely, oh Lord....

Where can I go from your Spirit?

Where can I flee from your presence?" (Psalms, 139:4).

To see how arguments for TWR work, it might be useful to spell out the argument from privacy more explicitly. It has two premises, one 'theological' and one evaluative:

Theological. If God exists, then, necessarily, He will know all our innermost thoughts, feelings and desires, as well as everything else we do.

Evaluative. Having no privacy is inherently bad. ${ }^{38}$

And TWR pretty much follows.

I don't expect many to dispute the 'theological' premise. It just follows from omniscience, one of God's essential attributes on the standard conception. It's important here that if God exists, then He necessarily knows everything. Knowing our innermost thoughts and feelings isn't something He chooses to do- or that He could choose not to do. ${ }^{39}$ It's just the way things are-necessarily are - in a Godly universe. So this isn't a case of God allowing some gratuitous evil. ${ }^{40}$ God isn't allowing anything, except in the indirect sense I'll discuss below. Notice also that no evil needs to be involved. I did phrase the evaluative claim in terms of badness, as seems appropriate here, but TWR only requires a comparative loss of good.

The evaluative premise is obviously more controversial. It can be defended directly: having each and every of my innermost thoughts and feelings open to

${ }^{38}$ To simplify things, I'll ignore here the distinction between personal and impersonal valueI'll assume here and below that the badness involved would be both personal and impersonal.

${ }^{39}$ But can't God restrict His knowledge in order to respect our privacy? It's rather unclear, however, what picture of divinity we get if we permit this move. If God needs to find out about our inner states only from publicly available information (which exactly?) as well as refraining from using His perfect intellect to still precisely infer our inner states even from that limited information, then we get a pretty dramatic revision in the standard theist picture of God's relation to His creatures. Now the standard picture may just be wrong. But I just want to highlight how revisionary such a move will be.

${ }^{40}$ Contra Kraay and Dragos (2013). 
another's view - even if it's someone perfectly benevolent - strikes me as deeply unwelcome, and as the remarks above indicate, this isn't an idiosyncratic response.

This response is supported by many influential accounts of the value of privacy. On some of these accounts privacy is valuable in itself while on others privacy matters because it is required for something else that is valuable, whether our dignity, or our having control over information about us or over others' access to us. ${ }^{41}$ To be sure, God isn't some ordinary peeping Tom, but the total divine invasion of our privacy will still be regarded as unwelcome on most of these accounts. And many would hold that the privacy of our inner lives is of far greater importance than the mundane privacy of our home or briefcase. And notice that the worry isn't that God would occasionally peep into our private matters but that, under God, we would have no privacy whatsoever.

Now many theists won't share these worries - this isn't surprising, since they should be used by now to God's constant prying presence. But-assuming that they don't simply reject the value of privacy, or see it as mattering only as a way of protecting us from malevolent parties - I think that the challenge is on those who reject this evaluative claim to explain why we should make an exception for God. I'll consider one such attempt below.

\section{WORSE IN RESPECT: STRUCTURE}

The argument from privacy nicely illustrates how arguments for TWR work. As we saw, their structure is as follows:

Theological. God's existence entails X.

Evaluative. $X$ is bad (or worse than X's absence).

Therefore

TWR. If God had existed, this would have been worse in important respects.

In assessing such arguments, it's important to distinguish questions about their abstract structure from questions about the evaluative claims they assume. The latter involves substantive moves within axiology and need to be assessed as such. You may reject these evaluative claims but that isn't the same as showing that arguments for TWR are incoherent.

The theological premise raises other complications. What is entailed by God's existence depends on how we conceive of God, and that is obviously a controversial matter. As I wrote above, I'll be assuming the widely held theist view that God is a supernatural being that is the omnipotent, omniscient and perfectly benevolent creator of the universe. It would be easy, but also uninteresting, to show that the existence of the unpleasant deity portrayed by many monotheistic texts and traditions would have nasty consequences. Conversely, if by 'God' we just mean love then our axiological questions aren't even worth asking.

What is challenging is to show how TWR might be true even on the standard theist conception of God as omnipotent, omniscient, and perfectly benevolent. Significant departures from this standard conception need to be justified since they would no longer be concerned with the supernatural being that people actually long for (or fear). And if we radically revise this standard conception it's unclear why we

${ }^{41}$ For such accounts, see Parent, 1983; Gavison, 1980; Moore, 2003; Bloustein, 1964. 
should be concerned with God at all — why not directly pursue the project of trying to identify the metaphysical system that is axiologically the best?

I stated the theological premise in terms of entailment. This is important since it explains how God's existence can make things importantly worse even though He's perfectly good. There is just nothing God can do about X. God is blameless. Job's wife advises him to curse God and die (Job 2:9). But the badness that God's existence brings to the world via $\mathrm{X}$ isn't a ground to complain against him - again, the claim isn't that God is wicked in some way.

Now there is admittedly a complication. All the ways that I can think of arguing for TWR involve the existence of people, contingent existences. To make this explicit:

Evaluative. $\mathrm{X}$ is bad (or worse) for (at least some) persons.

So God's existence would entail X only given the existence of the relevant persons, and that existence is a contingent matter-very much within God's power. But if so, why should God create beings whose inner privacy He would then necessarily go on to violate?

This point does complicate the argument, but it doesn't block it.

We can think of this issue in terms familiar from discussion of the problem of evil. You could say that, in creating the relevant persons, God is allowing them to suffer an evil they don't deserve. Now theists often hold that for an evil to be permitted by God, it must either be needed to secure a sufficiently significant, otherwise unobtainable good, or to prevent a sufficiently significant, otherwise unpreventable evil. ${ }^{42}$ It seems to me that the good of creating persons easily meets this condition. ${ }^{43}$ For surely, a world with persons who endure such badness (or loss of good) would still be far better - within the range of options available to Good - than a world without any persons at all. ${ }^{44}$

Conversely, if there isn't such a sufficient outweighing reason to create persons, then a Godly world would be one without persons at all which, besides involving very significant loss of impersonal value, would obviously be worse (or at least no better) for us. Why should we prefer such a world? So it seems the anti-theist has nothing to worry about here. ${ }^{45}$

Although TWR may be a surprising claim, I believe that it is compatible with standard conceptions of theism. Even if God is supremely good - the best conceivable being-His existence can still make things worse in significant respects. Perhaps there

${ }^{42}$ See Kraay and Dragos (2013).

${ }^{43}$ Kraay and Dragos (2013) seem to me to conflate this fairly limited point with the very different claim that God must necessarily compensate for this loss of good compared to a world in which God doesn't exist and persons don't have to endure such invasion of privacy. The claim that God won't allow gratuitous evil—which operates within a world —in no way entails this much stronger claim.

${ }^{44}$ So the full argument really goes like this:

(1) God's existence entails X.

(2) $\mathrm{X}$ is bad (or worse) for (at least some) persons.

(3) The badness of $X$ is outweighed by the value of the existence of persons (and what would logically and causally follow from that existence).

(4) If God exists, He will create the relevant persons, or allow them to come to exist (follows from (3) and God's essential properties).

Therefore

(5) TWR. If God had existed, this would have been worse in important respects.

${ }^{45}$ Notice also that if this claim is correct then the anti-theist argument turns into an instance of the problem of evil when applied to the actual world: since we do exist, God probably doesn't. 
is no plausible evaluative premise that, when conjoined with God's essential properties, would support TWR. But that is a substantive claim about value, not a denial of the coherence of the above form of argument.

Before moving to such questions about value, let me consider one extreme way in which one might attempt to block the argument. It might be argued that if God's very existence would make the universe worse then God would respond by committing self-deicide-by ending His own existence. ${ }^{46}$

Even if we set aside the view that God exists necessarily, or that He is needed to sustain the universe, this suggestion still involves a radical departure from mainstream theism. In any event, the mere fact that God's existence would make the world worse in some respect is hardly a good reason for Him to remove Himself from the scene. He would perhaps have reason to do so if His existence made the world overall worse compared to His non-existence, a far stronger claim. Indeed, even if His non-existence would make things overall better this won't immediately give Him reasons to kill himself for us, so to speak (and of course in a much stronger sense than claimed by Christianity) - it would do so only on a consequentialist view.

But let's take the idea of self-deicide seriously for a moment. It would give us something close to the Deist universe where God created the universe and then removed Himself from the scene. Applied to the actual world, we don't get a universe terribly different from a naturalist alternative - certainly not one that seems a great deal better. Or if it is better-say because God also left behind a working afterlifethen it's hard to see how it could be interestingly better than the supernatural alternative in which we get the afterlife without an initial Godly push. Indeed, a world in which God, the supremely good being who is our creator, had to vacate the scene for our sake is one that is likely to arouse in us an immense sense of guilt. It doesn't seem an appealing proposition.

\section{WORSE IN RESPECT: SUBSTANCE}

Having argued that it is coherent to hold that God's existence might make things worse in important respects, I turn now to the substantive question of whether we can identify unavoidable implications of God's existence - things that would simply follow from God's essential properties (and the existence of persons) - and which are also bad, or would lead to considerable loss of good, compared to relevant alternatives in which God doesn't exist.

I have already given one example of how one might fill out such an argument, appealing to the essential property of omniscience and to the badness of loss of inner privacy. There are other ways of filling out such arguments for TWR - for example, divine providence might undermine genuine freedom, and God's existence might mean that our ability to understand the universe is severely constrained - both undesirable implications. The existence of an omniscient God and heaven and hell may also make it practically impossible to act purely for the sake of virtue, and some have even argued that God's existence is incompatible with morality (Maitzen 2009).

It seems to me, however, that the deepest argument for TWR revolves around a set of related concerns relating to the hierarchical character of a theist universe or, in Nagel's (1997) words, about the idea of a 'cosmic authority' ${ }^{47}$ In such a universe

${ }^{46}$ See Kahane (2011).

${ }^{47}$ This is a common antitheist concern though it's often stated in unhelpful ways. For example, although Russell longed for God he was also a profoundly ambivalent pro-theist, writing that " $[t]$ he whole conception of God is a conception derived from the ancient Oriental despotisms. It is a 
we necessarily occupy a subordinate position in relation to a being that is vastly superior to us in every respect. That this supreme being is utterly benevolent is besides the point. The worry is about the position we occupy in such a world, not that God might abuse His power over us.

This basic idea can be developed in a number of more specific ways. To begin with, I think that the worry about loss of privacy can be assimilated to this larger concern. It isn't by accident that the idea that our inner lives will be under constant surveillance reminds us of a dystopian totalitarian regime. ${ }^{48}$

The worry about privacy is generated by God's omniscience. A further worry is generated by God's status as creator. If our existence, and the existence of everything that matters to us, is due to God, then it seem we owe Him a debt. It may also mean that it would be wrong for us to do as we will with God's creation, and perhaps even with ourselves.

Many theists also hold that God isn't only the creator but also continues to sustain everything that exists. That would mean that our moment by moment existence causally depends on Him, and that we are, in a way, constantly being acted upon by another person (for better or worse, there's no real solitude in a theist universe).

This worry about dependence goes deeper. If God created the universe, and us within it, He presumably did that for a purpose. ${ }^{49}$ If there is such a cosmic plan, and we (and others) are here to play our part in it, this severely constrains our ability to lead our lives according to our own plan. Even if it is permissible for us to just reject our role in God's plan (which is far from obvious), that rejection would surely have a cost. In acting in this way we might be interfering, even if only marginally, in the cosmic plan. To reject one's role in the divine plan isn't the same as being entirely free from the pressures of such a plan.

Perhaps most fundamentally, if God exists His moral status would be vastly higher than ours. We would not be equal members in a Kingdom of Ends but somewhere fairly low in the cosmic moral hierarchy. This seems undesirable in itself but is also likely to have concrete normative implications, such as duties to obey God and to worship Him (as the hymn says: 'Thy way, not my, oh Lord'). There is something deeply undignified in occupying such a subservient position, in surrendering one's will to that of another, however supremely benevolent. ${ }^{50}$

conception quite unworthy of free men." (Russell, 1957). Christopher Hitchens (2001) similarly describes the theist heaven in unflattering terms, a place of "[e]ndless praise and adoration, limitless abnegation and abjection of self; a celestial North Korea." Elsewhere Hitchens explains that he doesn't want theism to be true because it would amount to a "permanent, invigilated, regulated dictatorship which you are told is for your own good." (Brown, 2011). And in a discussion with Nasrallah, Julian Assange asked "shouldn't you as a freedom fighter also seek to liberate people from the totalitarian concept... of a monotheistic God?" (on Assange's RT show The World Tomorrow, 17 April 2012). These claims all seem to express the antitheist concern I'll be developing. But they fail to distinguish concern about the existence of a supremely benevolent being from far more obvious concern about some petty, vindictive deity.

${ }^{48}$ See Bloustein (1964) for a relevant attempt to ground the value of privacy in Kantian concerns about dignity.

49 The Catholic Catechism says: "God made me to know Him, love Him, and serve Him in this life and to be happy with him for ever in the next."

${ }^{50} \mathrm{C}$. Stephen Evans writes that if God exists, then our relation to Him "carries with it distinctive obligations... A proper social relation with God is one that requires humans to recognize the enormous debt of gratitude they owe to God, as well as the value of an on-going relation to God. Most religious believers have seen this relation to God as one in which God rightly has authority over them." This authority, Evans adds, might even be due to "God's ownership rights as creator"! (Evans 2013, 
If God exists, I should add, we would also be utterly insignificant compared to Him. By contrast, as I've argued elsewhere, in a naturalist universe we have at least a shot at being truly cosmically significant (Kahane 2014).

The list could be continued but I think it conveys the core idea. It obviously ties to the worry that God's existence is in tension with our autonomy. ${ }^{51}$ But I find it more useful to describe this cluster of worries as the broader concern that our independence would be severely curtailed if God exists. In such a universe, our ability to shape and govern our own lives, to define our own purposes and stand independent, our own masters, would be dramatically limited.

There is a sense in which, in a theist universe, we remain in a child-like state, unable to fully grow up to become completely independent persons who are fully in charge of their own lives and who are the moral equals of all other persons. We can put this schematically as follows:

(I) If God exists, then we will necessarily always be in relation to Him as young children are to their parents.

(II) Remaining forever in such a child-like state is undesirable.

Adam Smith thought there was 'nothing more melancholy than the suspicion of a fatherless world' (Smith 2002, VI.ii.3.). But for the antitheist the idea of a divine parent is precisely the problem.

The analogy to childhood needn't be taken too literally. But it does capture, it seems to me, the basic relation between us and God. Indeed in many respects the analogy doesn't go far enough - the gap between a child and her parents is not remotely as vast as that between us and God. You might even say that, in a Godly world, the parent-child relation is a faint echo of the relation between God and us.

But it's worth noting that, on common theist views, it would literally be true that we are God's children, and that any aspiration to complete independence and maturity is misguided. For example, the Catholic author Peter Kreeft writes that

“... all of us, even in Heaven, are children. And by the standard of the infinite, inexhaustible perfection of God, we remain children forever. Happy children, fulfilled children, but children... would we choose the childlikeness of Heaven or the promise of 'maturity', of 'humanity come of age' in Hell? Will we suffer gladly the blow and shock to our pride that is Heaven's gift of eternal childhood (thus eternal hope and progress) or will we insist on the 'successes' of 'self-actualization' that Heaven denies us and Hell offers us? (Kreeft, 1990).

If you remove the references to Heaven and Hell, this is actually a nice statement of the core antitheist concern. Maturity and self-actualization is precisely what the antitheist chooses - though, importantly, the antitheist needn't hold that we should attempt to fully realize these values if God exists; that would be futile, even absurd.

\footnotetext{
28; cited in Penner 2015).

${ }^{51}$ Rachels (1997). Rachels deploys this concern in an interesting but ultimately unpersuasive argument against God's existence. But I think Rachels's claims have more force when interpreted in antitheist terms. For another argument that has strong affinities with the antitheist argument I'm developing here, see Johnston (2011, 50-52), though Johnston goes on to defend a form of panentheism that is supposed to be compatible with metaphysical naturalism.
} 
Of course, Kreeft and other theists think that this is the wrong choice. For them eternal childhood is a wonderful gift. This isn't surprising. A traditional theist outlook is not especially conducive to placing great value on us being autonomous agents plotting an independent course through the world based on our own conception of the good. It's not by accident that recognition of the value of privacy, autonomy, and independence historically emerged in the Enlightenment, when the hold of traditional religious ideas started to wane. Kant famously described the Enlightenment as our emergence from 'self-incurred immaturity' (Kant 1970). ${ }^{52}$ The antitheist thinks that in a theist universe our immaturity isn't only self-inflicted but also God-imposed. As Heinrich Heine wrote, "we are free, and we want no thundering tyrants; we have reached majority and can dispense with paternal care." (Heine 2007) ${ }^{53}$

These antitheist worries aren't idiosyncratic concerns marshaled out of mere metaphysical anxiety. They reflect familiar and deep-rooted moral ideas, even if these are applied in an unusual context. The egalitarian idea that there is something deeply unattractive in being in a subservient position — and that we should reject such a position even if it brings with it considerable benefits - is a central moral idea in Western thought from the Enlightenment onwards. It underlies modern conceptions of democracy, and our rejection of slavery, caste, sexism, racism and other hierarchical moral systems.

Think, for example, of our distaste for servility - the wife who follows her husband's every order, or butler whose entire life is devoted to serving his masterimportantly, a distaste that remains even if the master is utterly benevolent and confers great benefits on the servile person. Such servility involves a failure of selfrespect, a failure to uphold one's dignity. This is usually taken to be due to failure to recognize one's true moral status, a moral status of equality with others (Hill Jr. 1973). Now in our relation to God, if God had existed, treating ourselves as vastly inferior to God wouldn't involve such an error. A kind of servility would, I assume, be appropriate. The antitheist isn't denying that. The point is rather that they find this a profoundly unattractive state to be in. To discover that God does exist would therefore be, in this respect, a deep disappointment.

Related concerns underlie the view that liberty requires non-domination (Pettit 1997). ${ }^{54}$ It's not enough to have the negative liberty to pursue a wide enough range of opportunities. The slave of a benevolent master can have such a range of opportunities, and the master needn't ever restrict this range. It remains the case, however, that the master is in a position of domination vis-à-vis the slave. It's in his power to take away these options as he wills, whether or not he actually does. It should be obvious that we cannot fully possess such liberty if God exists-we are utterly dominated by Him. God's supreme benevolence does nothing to alter this fundamental hierarchical relation. (As Frederick Douglass wrote, 'it was slavery-not its mere incidents - that I hated' (Douglass 1855, 161)). ${ }^{55}$

Notice that while a lack of complete inner privacy is directly entailed by God's omniscience, many of the antitheist concerns about independence admittedly

\footnotetext{
${ }^{52}$ Concern about independence has an admittedly Kantian flavor, and Kant himself held that "kneeling down or groveling on the ground, even to express your reverence for heavenly things, is contrary to human dignity." Kant (1994, 99; cited in Rachels 1997).

${ }^{53}$ Heine, however, was a pantheist idealist rather than a naturalist in the contemporary sense.

${ }^{54}$ Similar concerns can be made in terms of 'externalist' accounts of autonomy. See Oshana (1998).

${ }^{55}$ Lemos (2016) has relatedly argued that if theism is true, then we humans are treated by God merely as means to some good end-a conclusion that Lemos sees as supporting a kind of Kantian antitheism.
} 
involve less straightforward claims about the normative implications of God's existence, and then the further claim that these are undesirable. That we are inferior in status to God, or should worship Him, aren't directly entailed by God's omnibenevolence or omnipotence. ${ }^{56}$ They are based in substantive normative claims ${ }^{57}$ Still, these normative implications (if not the evaluative claims about their undesirability) are widely accepted by theists, and seem to me plausible. The core antitheist argument for TWR, however, doesn't require that they are all correct or that they take exactly the form assumed by theists. And it seems to me very doubtful that they are all false. Is it really remotely plausible that we have the same moral status as God-that we are His moral equals?

\section{FOUR OBJECTIONS}

The core argument for TWR rests on a cluster of evaluative claims relating to independence. These claims are based on direct reflection on what a theist world would be like but they are also grounded in familiar and widely held moral ideasideas that are central to modern moral thought.

Now there is a limit to what can be done to persuade those who reject these evaluative claims. But that is true of any fundamental evaluative disagreement. And, again, it's not hard to explain why theists wouldn't place great value on independence. Moreover, some prominent theists do concede that the implications of God's existence aren't entirely welcome. Peter van Inwagen admits that a life "where I am free to live my life according to my own desires" rather than a cosmic purpose is attractive to some people (van Inwagen 2009, 203-4), and Alvin Plantinga remarks on the "the serious limitation of human autonomy posed by theism," and which he sees as motivating atheism. ${ }^{58}$ Elsewhere he concedes that

"Theism severely limits human autonomy. According to theism, we human beings are also at best very junior partners in the world of mind. We are not autonomous, not a law unto ourselves; we are completely dependent upon God for our being and even for our next breath." (Plantinga 2012).

Plantinga doesn't dismiss these concerns and, for all I know, might endorse TWR.

There is little I can do to persuade those who place no value at all on independence. But I wish to consider several possible objections that could be made by those who do accept that independence matters.

1. It might be objected first that we do possess a significant degree of autonomy in a Godly world. We are free to align ourselves with God's will or even reject it, to live our lives according to His plan or to ignore it or even rebel against it. ${ }^{59}$

56 Though if Rachels (1997) is correct that it's constitutive of God that we have a duty to worship Him then this would simplify my argument. For an argument against such a duty, see Bayne and Nagasawa (2006).

${ }^{57}$ Kraay and Dragos $(2013,164 \mathrm{ff})$ also highlight this point. But I think they fail to see that the same applies to many familiar theist claims. They describe the view that God won't allow gratuitous evil as entailed by God's essential properties - but that claim similarly involves a substantive (if less controversial) unpacking of what it would mean to be omnibenevolent. Setting aside revelation, standard theist claims about cosmic justice or the afterlife are also not mere logical entailments of God's essential properties.

${ }^{58}$ Gutting (2014).

${ }^{59}$ Cf. Klaas and Dragos (2013); Davis (2014); Penner (2015); MacLean (2015). 
Conversely, even if naturalism is true, we would be far from being absolutely independent. Perhaps there is no supernatural being who sustains our existence, but we are fragile and dependent on other people, and our liberty to do as we please is severely constrained by both nature and human law.

Now it has been argued that God's existence is simply incompatible with genuine autonomy (Rachels 1997). But my argument doesn't depend on any such strong claim. The point is rather that there is an inherent constraint on how independent we can be in a Godly world. This, as I hope to have shown, is not a marginal difference, having a bit less of a good thing. The difference is fundamental. Children have a measure of freedom but they aren't independent adults. Indentured servants can have plenty of options to choose from, and can disobey or even rebel, but they aren't free persons.

The hierarchical character of a Godly world is its most fundamental fact, the fact around which life must revolve. There is nothing remotely comparable in the naturalist world. Even slaves and servants are, nevertheless, the moral equals of their masters. And the majority of us do not live lives centered around an all-powerful superior - not, that is, if we aren't theists. We are dependent on many others, but, again, these others are our moral equals. And the institutions and laws that constrain us still ultimately rest, if they are legitimate, on our joint wills. Finally, even if we must depend on each other, humanity as a collective isn't constrained by any others' will.

In any event, the comparison made in TWR needn't be true of all atheist worlds, not even of all naturalist ones. In fact-and this marks an important difference from the antitheist argument in Kahane (2011) — although I think that TWR also applies to the actual naturalist world, it's enough for the argument for superior atheist worlds if TWR is true with respect to some atheist worlds. In these conceivable worlds, we could be even more independent than we are here - and without an overbearing divine father in the background.

2. The critics might go on the offensive at this point. They might argue that things are actually significantly worse, with respect to independence, in a naturalist universe. To begin with, in a theist universe we will possess full-blown libertarian freedom yet there is no space for such freedom in a naturalist world. One naturalist who ridiculed the idea of such freedom was Friedrich Nietzsche. But Nietzsche also argued that the idea of moral equality is itself a relic of the religious worldview, a fantasy to be discarded by clear-eyed atheists. ${ }^{60}$

If Nietzsche were right, then this would puncture the antitheist argument. But few if any accept these claims of Nietzsche (though even if they were correct, the argument would still have force for those of us at the top of his unpleasant hierarchy). As for libertarian freedom, it is not obvious that we cannot have it in a naturalist universe (that we do not in fact posses it), and if we can't, it's not obvious that we can have it anywhere - the very idea might be incoherent. It is also unclear whether such freedom necessary or even important for independence in the sense outlined above. Finally, there is the last point made in reply to the previous objection: even if libertarian freedom was both a genuine possibility and needed for independence, then if don't and can't have it here, we could have it in a counterfactual atheist world (naturalist or not). And that world would be better for independence for any theist counterpart.

\footnotetext{
${ }^{60}$ See e.g. Leiter (forthcoming).
} 
3. It's important not to confuse a concern about independence with a desire for 'anarchy' ${ }^{\prime 1}$ or 'chaos' ${ }^{62}$. It may be that some antitheists wish to be a God-like source of everything - the narrator of Dostoevsky's Notes From the Underground complains about the immutability of $2+2=4$. And the extent to which antirealist naturalist accounts of value, morality, mathematics and the like are correct is an open question (though if you want to be the source of everything you should hope for idealism, or even solipsism, not for naturalism). But desiring everything to depend on you isn't the same as wanting to be independent. Independence requires a resistant reality external to the will (you need something to be independent $o f$ ). Otherwise the idea of pursuing one's own projects and life plan makes no sense. An independent humanity faces the challenge of mastering blind, indifferent nature - as well as its own many deficiencies. There could be no such challenge, or achievement, if nature were merely the projection of our own wills. In fact, it seems to me that the naturalist universe-a mindless universe that allows no magic or (efficacious) prayer-is superior in this respect to a theist one.

4. It might be argued, finally, that limits to our independence (and to our privacy) are a good thing in some cases - and that our subservient relation to God is one such case. God is, after all, our creator, and a supremely benevolent being.

We can dismiss the appeal to benevolence. As we saw, the worry isn't that our superior will misuse or abuse that position. What is unwelcome is the subservient position itself. And appealing here to God's supreme status doesn't really address the concern since, in a sense, the concern is precisely about that status.

Kraay and Dragos attempt to defend the suggestion that it isn't "always bad to be morally subordinate to some person's demands" by pointing that "children... are properly considered moral subordinates to their parents." They similarly suggest that "some restrictions on privacy are not bad at all, but entirely appropriate and justified", again giving the example of "certain restrictions that parents may place on their children's privacy." (Klaas and Dragos 2013, 165).

However, you cannot address a concern about forever remaining a childlike subordinate by appealing to what is appropriate for children! Moreover, children do not yet posses the capacity for genuine independence while adult humans do. And childhood is but a stage on the way to maturity; but in a theist universe we remain child-like for eternity. Klaas and Dragos also fail to distinguish here between value and justification. The argument was that the inherent constraints on our independence in a Godly world make such a world worse. The claim isn't that God would be wrong, or unjustified, in expecting our allegiance - again, our duties of allegiance would simply follow from the fact that we inhabit a world in which God exists, and I'm assuming that God would be justified in bringing us into existence despite that unwelcome imposition. (I should add that past a certain age, impositions on the privacy and will of children seem to me to involve a degree of badness despite being overall justified.)

Now I know that some people would choose blissful eternal servitude over a short, and far from blissful, (imperfect) independence. I don't want, or need, to criticize such a preference. I do want to highlight the considerable costs involved in such a life, and the aim of my earlier antitheist argument was only to show that a rejection of this cost - the rejection of eternal childhood or servitude - is rationally and morally permissible. In any event, this point has no bite against the current

\footnotetext{
${ }^{61}$ Kraay and Dragos $(2013,166)$. See also Penner (2015).

62 van Inwagen, 2009.
} 
argument. If you wish for eternal bliss, you should wish for eternal blissful independence.

\section{OVERALL VERDICTS}

I've argued that God's existence would make things worse in important respects and that most of the benefits that are supposed to follow from God's existence can also be had in many godless worlds. Together, these premises suggest that there must be atheist worlds that offer the benefits of God's existence without the cost - and that these should therefore be the best worlds. But there are number of complications which we need to attend to before we can assert this conclusion.

We can start by considering whether this overall verdict can be made at the impersonal level. As we saw earlier, one obstacle is God's own immense value, which is obviously missing from all atheist worlds. From that immense positive value, we need to deduct the badness or loss of good that God's existence would also bring about in worlds that contain persons. To that we may also add the badness for God of being the source of all that badness. But I cannot pretend to be able to confidently add these up to an overall verdict.

To complicate things further, it might be held that God's value isn't merely immense, but infinite. It's important to see, however, that this won't in itself tip the overall balance in favour of Godly worlds. Atheist worlds may be spatiotemporally infinite in size and thus potentially contain an infinite amount of value; in fact, we cannot even rule out that the actual naturalist universe is infinite in this way. ${ }^{63}$ So to claim that God's value makes theist worlds superior to all atheist ones requires us to rank some infinite worlds as better than others. But even if we could produce such a ranking I don't see why we must assume that Godly worlds must rank here as superior to all atheist ones.

Luckily, the Argument for Superior Atheist Worlds doesn't require us to resolve these questions. For us to be justified in preferring some atheist worlds to all theist alternatives it's enough, I believe, if (i) these atheist worlds are not impersonally overall worse in any significant way and (ii) these atheist worlds are overall superior to all theist alternatives from our personal perspective, in the sense of containing the personal benefits of a theist world while avoiding its harms.

I think (i) would be hard to deny. The relevant atheist worlds would be incredibly good. They can contain perfect justice, no suffering or other evils (at least not of the gratuitous kind), eternal blissful life, etc. The only significant thing they lack is God Himself. So even if one insisted that a Godly world is somewhat better, we would not be rejecting, on purely selfish grounds, some incredibly rosy universe in favour of a miserable, unjust one - as we seem forced to do if we try to defend actual world anti-theism.

So let me turn to (ii). If, as I had argued, God's existence makes our lives considerably worse by severely constraining our independence (and potentially for further reasons) while we can get the benefits that would follow from God's existence in some atheist worlds, then surely our lives in these atheist worlds would be better, and what we should most prefer.

Worries about infinite value again complicate things, though now in the other direction. If people enjoy immortality in both of these alternatives, then perhaps they

${ }^{63}$ See Bostrom (2011) for discussion of this possibility as well as of obstacles for claiming that one world containing infinite value is better than another. 
enjoy lives that are infinitely good in each case. So my argument seems to commit me to rank certain infinitely good lives as better than others. However, I think that such a ranking is straightforward here. A life that is eternally blissful and independent is surely superior to one that involves eternal bliss and submission.

In fact it seems to me that we have strong reasons to most prefer the former worlds even if we hesitate to call them better. We can think of these reasons as quasideontological in character: we should prefer those worlds where we don't suffer certain indignities even if these worlds are not overall better for us. Indeed, considerations relating to threats to our autonomy and independence are widely taken to be the primary ground of deontological reasons to act in ways that may be suboptimal, and it's only natural to extend this to attitudes such as preference. For my argument, I just need the weak claim that such consideration can tip the balance in cases where the competing options are, or may be, of equal value. But if we accept such deontological constraints on attitude then they are likely to extend further, allowing or even instructing us to reject worlds that are axiologically superior but nevertheless compromising. If so, this will greatly extend the range of atheist worlds that would count as preferable to all theist alternatives - arguably, including the actual miserable naturalist world, thereby also giving us a strong argument for actual world anti-theism. But I won't defend this stronger claim here. ${ }^{64}$

\section{THE BEST OF ALL POSSIBLE METAPHYSICAL SYSTEMS}

This concludes the Argument for Superior Atheist Worlds. As we saw, it is strongest when understood as a claim about which worlds are best, and most preferable, from our personal perspective. Parallel claims about the overall impersonal value of worlds are harder to resolve one way or the other, though it can hardly be ruled out that some atheist worlds are superior to all theist ones even in the impersonal sense.

If this is so, then Leibniz was wrong to claim that God must create the best of all possible worlds: God would be absent from the best worlds, and God obviously can't create those worlds that weren't created by God... (Leibniz's claim will hold only narrowly: God must create the best world out of those that He can create.)

It's important not to misunderstand my aim here. This isn't a niceness competition between theism and atheism (and, again, there is little in common between naturalism and some of the more fantastic atheist metaphysical systems). The point is that if you feel dissatisfied with what the actual naturalist universe has to offer, if you feel deprived of something further, then you should think seriously of what the best (or at least more satisfactory) universe would look like. But God needn't figure prominently in such reflections, let alone be assumed to figure in their outcome. To assume that is to dramatically underestimate the relevant range of options. ${ }^{65}$

Indeed, why expect that the ancient musings that are codified in the main world religions - musings shaped by factual ignorance, social utility and

\footnotetext{
${ }^{64}$ A third line of argument would claim that the evils we incur if God exists (or goods we lose) are lexically more important than even infinite amounts of 'lower' goods such as bliss.

65 The idea that we should explore alternatives to both (mainstream) theism and (hard) naturalism has been recently defended by others - see e.g. Schellenberg (2016); Nagel (2012). But these authors hold that some such alternative might actually be true. My claim is rather that such alternatives describe the best worlds we can conceive; it's incredibly unlikely that our world is anywhere close to being the best.
} 
psychological need, and by evaluative and moral assumptions we now find deeply wrong, often repugnant - not to mention, musings aiming to offer a true view of the actual world - be any kind of deep (let alone conclusive) guide to what might be best? This is a question we would do well to severe from the question of what is actually the case.

Now religious ideas can certainly provide material for reflection here-if, for example, the idea of heaven is an attempt to imagine a perfect form of life then it is useful input. But the idea that we first need to go through a vale of sorrows in our mortal life before going to heaven seems to me to have little plausibility except as a feeble way of addressing the obvious point that the actual world clearly isn't anything like heaven...

\section{TWO KINDS OF ANTI-THEISM}

I have argued that that there are some atheist alternatives that are superior to all theist ones (superior world anti-theism). This conclusion is compatible with holding that a theist alternative is superior to the actual naturalist world (actual world pro-theism). But it makes that view rather uninteresting, at least for a confident atheist. After all, there are tons of alternatives that are better in various ways from the actual world - not to mention, tons of alternatives that are far worse. Except for historical, sociological and perhaps dialectical reasons, there is no special reason to single out the theist alternative. It's not the best, or what we should most prefer. And, compared to many atheist alternatives, it brings with it considerable costs — costs that make it significantly worse even compared to the actual world. ${ }^{66}$

Even if you prefer the theist alternative to the actual naturalist world, it hardly follows that you want God to exist. Indeed, you may dread this prospect. (Compare: if you prefer a toothache to a broken leg, this hardly entails you want to have a toothache!) What you should really want is for one of the superior atheist alternatives to be true. In a perfectly good sense, you should still want God not to exist. But it's enough for my purposes that you have powerful reasons not to want God to exist. ${ }^{67}$

Moreover, to the extent that this argument is successful then it has the implication that theists should be anti-theists - not in the sense of wishing for the godless naturalist universe of Dawkins and Hitchens, but of wishing for these superior godless alternatives.

Conversely, if you hold that we should prefer the actual naturalist world to a theist alternative, this hardly means that you're in any way satisfied with the way things are. You don't want a world governed by a God. But you may still feel that something is missing in this world. You may wish that we had inhabited one of these

\footnotetext{
${ }^{66}$ Given that McGinn started out a theist, it was reasonable for him to feel disappointed when discovering that the world is considerably worse than he thought it was - even though it was also better in important respects. The question is what, now that (as I assume) McGinn is a confident atheist, he should feel about naturalism and theism. My argument is that he needn't pay much attention to theism, axiologically speaking. To the extent that regrets the way things are, or reflects on how they could have been better, he should focus on atheist alternatives. There is no reason to find God's absence regrettable.

${ }^{67}$ As I indicated several times, these considerations shift if we treat the truth of theism as a serious option. That could justify singling it out within that large space, despite it being inferior to some atheist possibilities_-if these aren't taken to be serious options.
} 
superior atheist worlds instead. Just as atheism isn't synonymous with naturalism, anti-theism certainly needn't commit us to pro-naturalism. ${ }^{68}$

\section{IF GOD IS IMPOSSIBLE}

The question of whether we should prefer a naturalist version of the actual world to a theist version, or even more generally the truth of theism to some naturalist alternative, is plagued by a now familiar modal problem. ${ }^{69}$ If God is a necessary being, there is no atheist alternative to theism. If the very idea of God is incoherent, there is no theist alternative to atheism. ${ }^{70}$ But does it make sense to prefer (or disprefer) what is anyway impossible, perhaps even incoherent?

Now both theists and atheists routinely make comparisons between theist and atheist alternatives. For example, William Craig declares: "in a universe without God, good and evil do not exist - there is only the bare valueless fact of existence" (Craig 2008, 75), while Dawkins asserts that "[y]ou can't escape the scientific implications of religion. A universe with a God would look quite different from a universe without one. ${ }^{71}$ If such comparisons make no sense then neither does much philosophy of religion.

It would be better, of course, to have a principled account of what is involved in such comparisons. ${ }^{72}$ And perhaps the problem doesn't even arise: plenty of atheists regard the idea of God as at least coherent, and some prominent theists deny that $\mathrm{He}$ is a necessary being. ${ }^{73}$ But here I just want to briefly relate this issue to the argument of this chapter. Since I'm not a theist, I'll focus on what would follow if theism isn't a genuine possibility. ${ }^{74}$

It's important to distinguish several issues here: (1) Are the alternatives being compared both genuine metaphysical possibilities? (2) If one is impossible, can we intelligibly ascribe value properties to, and within, such 'impossible worlds'? (3) Even if we can ascribe such value properties, do such impossibilities matter? That is to say, are they fitting objects for attitudes such as fear, relief or even just bare preference?

But suppose that these challenges can't be met and that theism isn't even conceptually possible or describes a metaphysical impossibility to which we cannot ascribe value or that such impossibilities don't matter.

This is obviously not something atheists need to worry about - for one, if this is correct, then they needn't worry about arguments purporting to show how bleak a naturalist universe is compared to the theist alternative. And such a conclusion would do no damage to the axiology of naturalism. No one seriously thinks that naturalism is necessarily true, let alone that the actual universe had to be that way. As we have seen, there is a vast space of possible atheist worlds, both natural and supernatural, to consider. Nor is there anything incoherent in the idea of cosmic justice or immortality.

\footnotetext{
${ }^{68}$ Nagel himself expresses both anti-theist and anti-naturalist sentiments-it's clear that he wants neither to be true. Since he also appears to deny that 'hard' naturalism succeeds in correctly describing the actual world, it's not obvious whether he'd prefer the truth of hard naturalism over that of theism.

${ }^{69}$ See Kahane $(2011 ; 2013)$. See also Mugg (forthcoming).

${ }^{70}$ Martin \& Monnier (2003).

${ }^{71}$ In a debate with Archibishop Habgood, 1992. Cited by Johnston $(2011,46)$.

${ }^{72}$ For discussion, See Kahane (2011); Kraay \& Dragos (2013).

${ }^{73}$ See e.g. Swinburne (1994).

${ }^{74}$ Cf. Findlay (1955).
} 
Of course, to the extent that we cannot intelligibly compare a theist universe to various alternatives, then many of the claims made in this chapter need to be reconfigured. But the main point could then be stated in even stronger terms: to the extent that people find the actual naturalist universe grim, or that they deeply regret that God doesn't exist, then they are doubly mistaken. It's not just that they are longing for the wrong thing, as I have argued, but for something that it makes no sense to long for. To the extent that they should wish that things had been different, they should focus not on theism but on those atheist counterfactuals in which we would have enjoyed the benefits associated with God's existence. We arrive at the same conclusion, it's just that the argument is much simpler.

\section{CONCLUSION}

Commenting on Nagel's remark that he doesn't want God to exist, Plantinga writes,

"here we have discomfort and distress at the thought that there might be such a being as God; but this discomfort seems more emotional than philosophical or rational." (Plantinga 2012) ${ }^{75}$

But Nagel may have good reasons for wanting God not to exist. What attitude we take to the possibility that God exists isn't merely a psychological fact about us. Anti-theism and pro-theism require philosophical and rational justification, which must revolve, in large part, around claims about the difference in value made by God's existence - I am assuming here, and Nagel and Plantinga will surely agree, that such evaluative claims aren't themselves merely expressions of emotions. In debating such claims, we may eventually reach deadlock, a point where an axiological gulf divides us from those who disagree with us. But that can happen with any disagreement about value.

When pro-theism is defended, this is usually by reference to the various goods that would follow from God's existence-immortality, cosmic justice, meaning, etc. In this chapter, I have argued that if you want God to exist because of such extrinsic goods then what you should really want is a godless world that contains these goods without the adverse implications of God's existence.

I've developed this argument from a naturalist, atheist standpoint. But I think it has disturbing implications for theists. It supports the conclusion that theists have strong reason to find it regrettable that God exists - and that they have this reason even if actual world pro-theism is successful. The axiology of theism leads to blasphemous conclusions...

I suspect it is anyway somewhat blasphemous for a theist to want God to exist simply because of the extrinsic benefits His existence would bring about. Shouldn't the devout believer want God's existence for its own sake, because she wants God to exist rather than because she fancies immortality? Perhaps even: regardless of what

${ }^{75}$ The assumption that disagreements on such matters are no more than temperamental differences is common. Peter van Inwagen (2009, 203-205) suggests that either 'chaos' or 'logos' can be emotionally attractive for certain people. Peter Godfrey-Smith (2013) similarly writes, in a review of Nagel's book, that "Darwinism offers a view according to which the evolution of awareness and reason is, in a broad sense, accidental. Some will respond by hoping for more, for a universe in which we are supposed to be here. Others might find that our deep contingency brings with it a peculiar sense of freedom". And Adam Gopnik (2014) remarks, of the wildly different responses of major poets to the absence of God, that "in the end, these seem questions more of temperament than of argument." 
benefits God may bring about, indeed, even if His existence would make things worse. The pro-theism of theists should be pure and unquestioning... But this comes close to saying that theists (and perhaps also those who seriously think that God might actually exist) shouldn't even raise these axiological questions. Perhaps the axiology of theism is permissible only to the unwavering atheist...

Naturalists don't face this problem. The indifferent and pitiless universe around us isn't something we can disrespect, let alone blaspheme against. Still, as I said earlier, we cannot read what attitudes we should have, overall, simply by considering the value of options. Even if we recognize that things could have been better in a zillion ways - that we have reason to prefer a supernatural (if atheist) alternative to the naturalist universe we inhabit-it doesn't follow we should dwell on these pale possibilities. Such daydreaming can seem immature, and may even be a kind of vice: a failure to pay proper respect, not, of course, to the miserable universe itself, but to the things in it that $d o$ possess value. ${ }^{76}$

Whether this is so, however, depends on a question I have not addressed here: on whether or not there is such a normative 'hole' in our universe or lives. Our world is rather miserable, and the evil that motivates the problem of evil doesn't go away when God 'departs'. Our lives may be lacking in some fundamental way. Just as it isn't wrong for the oppressed citizens of a dystopia to reject the remaining glimmers of good, then we would also be entitled, if this is the case, to be dissatisfied with the universe we find around us. ${ }^{77}$

\section{REFERENCES}

Adams, Robert, 1979. "Moral Arguments for Theistic Belief," in Rationality and Religious Belief, C. Delaney (ed.), Notre Dame: University of Notre Dame Press, pp. 116-40.

Aquinas, Thomas. 2006. Summa Theologica. Raleigh, NC: Hayes Barton Press.

Augustine. 2008. Confessions. Translated by Henry Chadwick. Oxford World's Classics.

Bayne, Tim and Nagasawa, Yujin. 2006. "The Grounds of Worship". Religious Studies, 42 (3): 299-313.

Bishop, John. 2009."Towards a Religiously Adequate Alternative to OmniGod Theism”, Sophia, 48: 419-433.

Bloustein, Edward J. 1964, "Privacy as an Aspect of Human Dignity: An Answer to Dean Prosser", New York University Law Review, 39: 962-1007

Borges, Jorge Luis 1962. "Tlon, Uqbar, Orbis Tertius", in Labyrinths, Penguin Books.

Bostrom, Nick. 2011. "Infinite Ethics". Analysis and Metaphysics 10: 9-59.

Brown, Mick. 2011. "Godless in Tumourville: Christopher Hitchens Interview”. The Telegraph, March, 25.

Büttner, Gottfreid. 2002. "Schopenhauer's Recommendations To Beckett". Samuel Beckett Today/Aujourd'hui, 11 (1), 114-122.

Byatt, A. S. 1967. In The God I Want, edited by James Mitchell. London: Bobbs Merrill.

${ }^{76}$ Nietzsche held an extreme version of this view, rejecting any transcendent otherworldly longing as life denying, and asking us to unwaveringly affirm the actual. For a much milder version of this claim, see Calhoun (2017).

${ }^{77}$ This chapter was presented at the philosophy of religion work-in-progress group at Ryerson University. I'm grateful to the participants for useful suggestions and to Klaas Kraay and Kirk Lougheed for extremely helpful written comments. 
Calhoun, Cheshire. 2017. “On Being Content With Imperfection”. Ethics 217 (2): 327-352.

Chalmers, David. 2007. "Naturalistic Dualism" in The Blackwell Companion to Consciousness, edited by Max Velmans and Susan Schneider, 359-368. Oxford: Blackwell Publishing.

Craig, William Lane. 2008. Reasonable Faith ( $3^{\text {rd }}$ Edition). Crossway Books.

Cudworth. Ralph. 1678. The True Intellectual System of the Universe. London.

Davis, S.T. 2014 "On Preferring that God Not Exist (or that God Exist): A Dialogue." Faith and Philosophy 31: 143-159.

Dawkins, Richard. 2008. River out of Eden: A Darwinian view of life. Basic books.

Dennett, Daniel C. 1984. Elbow Room: The Varieties of Free Will Worth Wanting. Cambridge, Mass.: MIT Press.

Douglass, Frederick. 1855. My Bondage and My Freedom. New York and Auburn: Miller, Orton and Mulligan.

Dumsday, Travis. 2016. "Anti-Theism and the Problem of Divine Hiddenness.” Sophia 55: 179-195.

Evans, C. Stephen. 2013. God and Moral Obligation. Oxford: Oxford University Press.

Findlay, John N. “Can God's existence be disproved?", in New Essays in Philosophical Theology, edited by Antony Flew and Alasdair MacIntyre, New York NY: Macmillan,

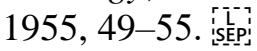

Freud, Sigmund. 1990. The Future of an Illusion in Civilization, Society and Religion, Penguin Freud Library, Volume 12, London: Penguin.

Gavison, Ruth. 1980, "Privacy and the Limits of Law", Yale Law Journal, 89: 421-71.

Godfrey-Smith, Peter. 2013. 'Not Sufficiently Reassuring', London Review of Books, January 24.

Gopnik, Adam. 2014. 'Bigger than Phil: When Did Faith Start to Fade?'. The New Yorker, February 17.

Griffin, Nicholas. 2013. The Selected Letters of Bertrand Russell, Volume 1: The Private Years 1884-1914. London: Routledge.

Gutting, Gary, 2014. "Is Atheism Irrational?". New York Times, February 9.

Habermas, Jurgen. 2010. An Awareness of What's Missing: Faith and Reason in a PostSecular Age. London: Polity Press.

Heine, Heinrich. 2007. On the History of Religion and Philosophy in Germany. Cambridge: Cambridge University Press.

Hill, Thomas E. "Servility and Self-respect." The Monist (1973): 87-104.

Hitchens, Christopher. 2001. Letters to A Young Contrarian. New York: Basic Books.

Housman, A. E. 1922/2010. "Tell Me Not Here, It Needs Not Saying”. in A Shropshire Lad and Other Poems: The Collected Poems of A.E. Housman. Penguin Classics.

Jackson, Frank. From Metaphysics to Ethics. Oxford University Press, 1998.

Johnston, Mark. Saving God: Religion After Idolatry. Princeton University Press, 2011.

Kahane, Guy. 2011. "Should We Want God to Exist?" Philosophy and Phenomenological Research, 82: 674-696. doi:10.1111/j.1933-1592.2010.00426.x

Kahane, Guy. 2012. "The Value Question in Metaphysics." Philosophy and Phenomenological Research 85: 27-55. 
Kahane, Guy. 2014. "Our Cosmic Insignificance”, Noûs, 48, 4: 745-772.

Kahane, Guy. 2016. "If Nothing Matters", Noûs. [DOI: 10.1111/nous.12146]

Kant, Immanuel. 1994. Ethical Philosophy. Translated by James W. Ellington. Indianapolis: Hackett.

Kant, Immanuel. 1970. “What is Enlightenment?" in Kant: Political Writings. Cambridge University Press.

Kraay, Klaas and Dragos, Chris (2013) “On Preferring God's Non-Existence.” Canadian Journal of Philosophy 43: 153-178.

Kreeft, Peter. 1990. Everything You Ever Wanted to Know about Heaven But Never Dreamed of Asking. Ignatius Press: San Francisco, 27-50.

Leiter, Brian, Forthcoming. "The Death of God and the Death of Morality". The Monist.

Lemos, John. 2016. "God's Existence and the Kantian Formula of Humanity." Sophia, 1-14.

Luck, Morgan and Ellerby, Nathan. 2012. "Should we Want God Not to Exist?” Philo 15: 193-199.

Maitzen, Stephen. 2009. “Ordinary Morality Implies Atheism.” European Journal for Philosophy of Religion 1 (2): 107-126.

Martin, Michael, and Ricki Monnier. 2003. The Impossibility of God. NY: Prometheus Books.

Mavrodes, George, I. 1986. "Religion and the Queerness of Morality." In Robert Audi and William Wainwright (eds.), Rationality, Religious Belief, and Moral Commitment: New Essays in the Philosophy of Religion. Ithaca, NY: Cornell University Press.

Mawson, Tim. 2012. "On Determining How Important it is Whether or Not there is a God." European Journal for Philosophy of Religion 4: 95-105.

McLean, G. R. 2015. “Antipathy to God.” Sophia 54: 13-2.

Mill, John Stuart.1874. "Theism” in Three Essays on Religion, New York: Henry Holt \& Co.

Miller, Jonathan. 2004. The Atheism Tapes: Colin McGinn, BBC.s[spep?

Moore, Adam, D. 2003, "Privacy: Its Meaning and Value" American Philosophical Quarterly, 40: 215-227.

Monk, Ray. 1996. Bertrand Russell: Spirit of Solitude. Free Press.

Mugg, Joshua. Forthcoming. "The Quietist Challenge to the Axiology of God: A Cognitive Approach to Counterpossibles." Faith and Philosophy.

Nagel, Thomas. 1971. "The Absurd". The Journal of Philosophy, 68 (20), 716-727.

Nagel, Thomas. 1997. The Last Word. Oxford: Oxford University Press.

Nagel, Thomas. 2009. "Secular Philosophy and the Religious Temperament" in Secular Philosophy and the Religious Temperament: Essays 2002-2008. Oxford University Press.

Nagel, Thomas. 2012. Mind and Cosmos. Oxford University Press.

Nietzsche, Friedrich. 2001. The Gay Science. Translated by Josefine Nauckhoff. Cambridge: Cambridge University Press.

Oshana, Marina A. L. 1998. "Personal Autonomy and Society." Journal of Social Philosophy 29 (1): 81-102.

Parent, William. 1983. "Privacy, Morality and the Law", Philosophy and Public Affairs, 12: 269-88.

Parfit, Derek. 2011. On What Matters, Vol. II. Oxford University Press. 
Penner, Myron. 2015. "Personal Anti-Theism and the Meaningful Life Argument." Faith and Philosophy 32: 325-337.

Penner, Myron and Lougheed, Kirk. Forthcoming. "Pro-Theism and the Added Value of Morally Good Agents." Philosophia Christi.

Pettit, Philip. 1997. Republicanism: A Theory of Freedom and Government. OUP Oxford.

Plantinga, Alvin. 2000. Warranted Christian Belief. Oxford University Press.

Plantinga, Alvin. 2012. "Why Darwinist Materialism is Wrong" (review of Nagel's Mind and Cosmos), The New Republic, November 2012

Rachels, James. 1997. "God and Moral Autonomy" in his Can Ethics Provide Answers? : And Other Essays in Moral Philosophy (Boulder: Rowman \& Littlefield Publishers, pp. 109123.

Rescher, Nicholas. 1990. "On Faith and Belief.” In his Human Interests. Stanford: Stanford University Press, 166-178

Russell, Bertrand. 1903. “The Free Man's Worship.” In L. I. Greenspan and S. Andersson (eds.), Russell on Religion: Selections from the Writings of Bertrand Russell. London: Routledge, pp. 31-38.

Russell, Bertrand. 1950. Am I an Atheist or an Agnostic? Haldeman-Julius Company (Girard, $\mathrm{KS})$.

Russell, Bertrand. 1957. Why I am not a Christian and Other Essays. George Allen and Unwin.

Sartre, Jean-Paul. 1964, The Words. New York: George Braziller.s[Ep]

Sartre, Jean-Paul. 2007. Existentialism is a Humanism. Yale University Press.

Scanlon, Thomas .M., 2014. Being Realistic About Reasons. Oxford University Press.

Schellenberg, J. L. 2016. "God For All Time: From Theism to Ultimism". In Buckareff, Andrei and Nagasawa, Yujin, eds., Alternative Conceptions of God. Oxford: Oxford University Press.

Sidgwick, Henry, 1907. The Methods of Ethics. Hackett Publishing.

Smith, Adam. 2002. The Theory of Moral Sentiments. Cambridge University Press.

Strawson, Galen. 2008. Real Materialism: and Other Essays. Oxford University Press.

Swinburne, Richard, 1994. The Christian God. Oxford: Oxford University Press. istep.

Taylor, Charles, 2007. A Secular Age. Harvard University Press.

van Inwagen, Peter. 2006. The Problem of Evil. Oxford: Oxford University Press.

van Inwagen, Peter. 2009. Metaphysics, 3rd edition. Boulder, Colorado: Westview Press.

Weinberg, Steven. 2008. "Without God”, New York Review of Books, September 25.

Williams, Bernard. 1973. "The Makropulos Case: Reflections on the Tedium of Immortality," in Problems of the Self. Cambridge: Cambridge University Press.

Wolf, Susan. 2010. Meaning In Life and Why It Matters. Princeton University Press. 